\title{
THE REVIEW OF POLITICS
}

University of Notre Dame Fall 1991 


\title{
THE REVIEW OF POLITICS
}

Acting Editor (1981-92) WALTER NICGORSKI

\author{
Editor \\ DONALD P. KOMMERS \\ Managing Editor \\ DENNIS WM MORAN
}

Book Review Editor

SHARON L. O'BRIEN

Philip Gleason

Associate Editors
E. A. Goerner

Alasdair MacIntyre

Thomas Werge
Waldemar Gurian

Former Editors

M. A. Fitzsimons

Thomas Striteh

Frederiek J. Crosson

Henry J. Abraham

Editorial Advisory Board
Charles W. Anderson

University of

Wisconsin-Madison

Shlomo Avineri

Hebrew University of Jerusalem

Robert F. Byrnes

Indiana University

Ernest L. Fortin Boston College

Gerald Garvey

Princeton University

Arend Lijphart

University of

California-San Diego
Theodore J. Lowi

Cornell University

Harvey C. Mansfield

Harvard University

Mary Nichols

Fordham University

Arlene Saxonhouse

University of Michigan

Kenneth W. Thompson

University of Virginia

Glenn Tinder

University of

Masswchusetts-Boston

Catherine Zuekert

Carleton College

Editorial Interns

V. Bradley Lewis, W. J. Thompson

The Review of Politics, without neglecting the analysis of institutions and techniques, is primarily interested in the philosophical and historical approach to political realities.

The articles in The Review of Politics are indexed in the International Index to Periodicals and the Index of Catholic Periodicals and abstracted in the International Political Science Abstracts. They are abstracted and indexed in ABC POL. SCI. and HISTORICAL ABSTRACTS and SOCIAL SCIENCES INDEX.

The Review of Politics (ISSN 0034-6705) is published quarterly for $\$ 25.00$ per year in the United States (Individual, $\$ 20.00$ ); foreign $\$ 28.00$ (Individual, $\$ 23.00$ ); single copies, $\$ 10.00$ (domestic) and $\$ 11.00$ (foreign) by The University of Notre Dame, P.O. Box B, Notre Dame, IN 46556. Second-class postage paid at Notre Dame, IN. POSTMASTER: Send address changes to The Review of Politics, P.O. Box B, Notre Dame, IN 46556. 


\section{THE REVIEW OF POLITICS}

Published Quarterly by the University of Notre Dame, Indiana

Vol. 53

Fall 1991

No. 4

Aristide Tessitore

Euripides' Medea and the Problem of Spiritedness 587

Philip AbBott

Are Three Generations of Radicals Enough?: Self-Critique in the Novels of Tess Slesinger, Mary McCarthy and Marge Piercy.................................................... 602

Donald W. Hanson

Reconsidering Hobbes's Conventionalism

Robert P. George

The Unorthodox Liberalism of Joseph Raz.

Margaret Moore

Liberalism and the Ideal of the Good Life

Review Essay:

J. Brian Benestad

Catholicism and American Public Philosophy

Reviews:

Kirk Emmert: Political Scientists and the American Regime

Review of James W. Ceasar's Liberal Democracy \& Political Science

Samuel B. Hoff: The Personal Candidate

Review of Martin P. Wattenberg's The Rise of Candidate-Centered Politics:

Presidential Elections of the 1980s

Gregory Bassham: MoRality AND the Constitution

Review of Graham Walker's Moral Foundations of Constitutional Thought:

Current Problems, Augustinian Prospects

Mark Tushnet: An Analytic Account of Rights

Review of Judith Jarvis Thompson's The Realm of Rights

Catherine Zuckert: A Heideggerian Strauss?

Review of Luc Ferry's Rights - The New Quarrel between the Ancients and the Moderns 
Christopher Kelly: The Systematic Rousseau

Review of Arthur M. Melzer's The Natural Goodness of Man: On the System

of Rousseau's Thought

Francis Canavan: THE Mind of EdMUnd Burke

Review of Peter J. Stanlis's Edmund Burke: The Enlightenment and Revolution

William B. Gwyn: A Moderate Type of Idealism

Review of Peter P. Nicholson's The Political Philosophy of the British Idealists:

Selected Studies .............................................................

Kevin J. Smant: Defining Conservatism

Review of Ted Honderich's Conservatism and Melvin J. Thorne's American

Conservative Thought Since World War II: The Core Ideas ....................

Jean Bethke Elshtain: Feminisms and the State

Review of Mary Lyndon Shanley's Feminism, Marriage, and the Law in Victorian England and Catharine A. MacKinnon's Toward a Feminist Theory of the State

Wilson D. Miscamble, C.S.C.: An American in Bonn

Review of Thomas Alan Schwartz's America's Germany: John J. McCloy and the Federal Republic of Germany

Theodore S. Hamerow: A More Human Bismarck

Review of Otto Pflanze's Bismarck and the Development of Germany

Alec Stone: Federalism in Canada

Review of Robert C. Vipond's Liberty and Community: Canadian Federalism and the Fcilure of the Constitution

\section{INSTRUCTIONS TO CONTRIBUTORS}

All manuscripts should be submitted in QUADRUPLICATE to The Review of Politics, Box B, Notre Dame, IN 46556. If the return of the manuscript is desired, a stamped, self-addressed envelope should be enclosed. All typewritten material should be double-spaced, including notes and quotations; photocopies of a good quality are acceptable. The Review follows the Chicago Manual of Style for standards of citation, punctuation and other editorial considerations. The normal length of manuscripts published is $25-30$ pages. Longer manuscripts will be evaluated in light of the limited printing space available. Since manuscripts are evaluated anonymously they should not bear the author's name or institutional affiliation. Submissions should be sent with an ABSTRACT of 100-150 words. All correspondence regarding book reviews should be sent to Dr. Sharon L. O'Brien at the above address. 


\section{Contributors to This Issue}

Aristide Tessitore is Assistant Professor of Political Philosophy in Assumption College. Philip Aввотт is Distinguished Graduate Professor of Political Science in Wayne State University. Donald W. Hanson is Professor of Political Science and Chair of the Department of Political Science in the University of Utah. Robert P. George is Assistant Professor of Politics in Princeton University. Margaret Moore is Assistant Professor of Political Science in York University, Toronto. J. BRIAN Benestad is Professor of Theology in the University of Scranton.

KIrk Emmert is Professor of Political Science in Kenyon College. Samuel B. Hoff is a member of the Department of History and Political Science in Delaware State College. Gregory Bassham is Adjunct Assistant Professor of Philosophy in the University of Notre Dame. Mark Tushnet is Professor of Law in Georgetown University's School of Law. CATHERINE Zuckert is Professor of Political Science in Carelton College. Ghristopher Kelly is a member of the Department of Political Science in the University of Maryland, Baltimore County. Francis Canavan, S.J., is Professor Emeritus of Political Science in Fordham University. William B. GWYN is Professor of Political Science in Tulane University. KEvin J. Smant is Adjunct Assistant Professor of History in Indiana University at South Bend. Jean Bethke Elshtain is Centennial Professor of Political Science and Professor of Philosophy in Vanderbilt University. Wilson D. Miscamble, C.S.C., is Assistant Professor of History in the University of Notre Dame. THEOdORE S. Hamerow is Professor of History in the University of Wisconsin, Madison. Alec Stone is Assistant Professor of Political Science in the University of California, Irvine. 


\section{NEW \& NOTEWORTHY} FROM MISSOURI

\section{The Confederate Constitution of 1861}

An Inquiry into American Constitutionalism Marshall L. DeRosa

D eRosa argues that the Confederate Constitution was not, as is widely believed, a document designed to perpetuate a Southern "slaveocracy," but rather an attempt by the Southern political leadership to restore the AntiFederalist standards of limited national government. 192 pages, $\$ 32.50$ (cloth) $\$ 14.95$ (paper)

\section{Plato's Political Philosophy}

Prudence in the Republic and the Laws Zdravko Planinc

\footnotetext{
T $\mathrm{n}$ this major addition to Platonic scholarship, Planinc offers a bold new interpretation of the Republic and the Laws. Arguing that scholars have misread these works for many years, he refutes the common conception of Plato as a political idealist and challenges conventional interpretations of two of the most influential works in the history of Western civilization. 304 pages, $\$ 37.50$
}

\section{Tradition and Authenticity in the Search for Ecumenic Wisdom Thomas Langan}

ur emerging world system is bringing the great traditions and cultures it has spawned into ever more intimate and dangerous contact. Langan argues that we must struggle toward a unity of discourse respectful of genuine experiences of varying civilizations if we are to live peacefully on one planet. 248 pages, $\$ 35.95$ 